\title{
Pengaruh belanja daerah terhadap pertumbuhan ekonomi dan kemiskinan Kabupaten/Kota di Provinsi Jambi
}

\author{
Rizky Airy Putri*; Zamzami; Selamet Rahmadi \\ Prodi Ekonomi Pembangunan Fak.Ekonomi dan Bisnis, Universitas Jambi \\ *E-mail korespondensi: rizky.airyputri1997@gmail.com
}

\begin{abstract}
The ability of local governments to manage finances is stated in the regional revenue and expenditure budget $(A P B D)$. The higher the regional expenditure allocation in the APBD, the higher the level of economic growth to reduce or alleviate the level of poverty. The variables that affect economic growth and poverty include regional expenditure. This study aims to determine the effect of regional spending on economic growth and poverty in regencies/cities in Jambi province partially or collectively. The analytical method used is simple regression analysis with a panel data model. The results showed that regional spending has a negative and partially insignificant effect on economic growth. Regional expenditure has a positive and minor impact on poverty levels in districts/cities in Jambi Province.
\end{abstract}

Keywords: Local government, Economic growth, Poverty.

\begin{abstract}
Abstrak
Tujuan Kemampuan pemerintah daerah dalam mengelola keuangan dituangkan dalam anggara pendapatan dan belanja daerah (APBD). semakin tinggi alokasi belanja daerah pada APBD menyebabkan semakin tinggi tingkat pertumbuhan ekonomi sehingga dapat mengurangi atau mengentaskan tingkat kemiskinan. Variabel yang mempengaruhi pertumbuhan ekonomi dan kemiskinan antara lain adalah Belanja Daerah Penelitian ini bertujuan untuk mengetahui pengaruh Belanja Daerah terhadap pertumbuhan ekonomi dan kemiskinan di Kabupaten/Kota di Provinsi Jambi secara parsial maupun secara bersamasama. Metode analisis yang digunakan adalah analisis regresi sederhana dengan model panel data. Hasil penelitian menunjukan bahwa belanja daerah memiliki pengaruh yang negative dan tidak signifikan secara parsial terhadap pertumbuhan ekonomi dan belanja daerah berpengaruh positif dan tidak signifikan terhadap tingkat kemiskinan di kabupaten/kota di provinsi jambi.
\end{abstract}

Kata kunci: Belanja daerah, Pertumbuhan ekonomi, kemiskinan.

\section{PENDAHULUAN}

Salah satu indikator keberhasilan daerah dalam kesejahteraan masyarakat nya adalah dengan peningkatan pertumbuhan ekonomi yang ditandai dengan peningkatan PDRB dari tahun ke tahun. Pertumbuhan ekonomi yang tinggi selalu menjadi salah satu hal yang ingin dicapai oleh semua negara maupun daerah. Berdasarkan badan pusat statisktik, Pertumbuhan ekonomi di Provinsi Jambi selama tahun 2015-2018 mengalami fluktuasi. Pertumbuhan ekonomi yang paling tinggi pada tahun 2015 adalah kota sungai penuh sebesar 7\%, pada tahun 2016 sebesar 6,5\% dan pada tahun 2017 sebesar 6,2\%.Pada tahun 2018 pertumbuhan 
ekonomi menurun sebesar $0,7 \%$.Sedangkan pertumbuhan ekonomi paling terendah adalah kabupaten sarolangun pada tahun 2015 sebesar -1,4\% . pada tahun 2016 meningkat menjadi sebesar 4,3\% dan pada tahun 2017 sebesar 4,4\%. Pada tahun 2018 meningkat dari tahun sebelumnya menjadi sebesar $4,7 \%$.

Kemiskinan didefinisikan kondisi dimana seseorang atau sekelompok orang, laki-laki dan perempuan, tidak terpenuhi hak dasarnya untuk mempertahankan dan mengembangkan kehidupan yang layak. Berdasarkan data badan pusat statistik memperlihatkan bahwa tingkat kemiskinan di provinsi jambi tahun 2015-2018 mengalami fluktuasi. tingkat kemiskinan paling tinggi pada tahun 2015 adalah sebesar 14,17\% di Kabupaten Tanjung Jabung Timur. Pada tahun 2016 menurun sebesar 12,76\% dan pada tahun 2017 sebesar 12,58\%. Pada tahun 2018 tingkat kemiskinan menurun sebesar 0,2\%.Sedangkan tingkat kemiskinan paling rendah adalah kota sungai penuh pada tahun 2015 sebesar 3,43\%. pada tahun 2016 mengalami penurunan menjadi sebesar 3,13\% dan pada tahun 2017 sebesar 2,78\% pada tahun 2018 tingkat kemiskinan menurun sebesar 0,02\%.

Anggaran Pendapatan dan Belanja Daerah (APBD) adalah rencana keuangan tahunan daerah yang ditetapkan berdasarkan peraturan daerah yang telah disetujui oleh Dewan Perwakilan Rakyat Daerah (DPRD) (Yuwono et al, 2005). Belanja Daerah digunakan untuk mendanai segala urusan pemerintah, Berdasarkan data badan pusat statistik belanja daerah di Provinsi Jambi tahun 2015-2018 mengalami fluktuasi. Belanja daerah yang paling tinggi pada tahun 2015 adalah Kota Jambi sebesar Rp1.426,80 Triliun.Pada tahun 2016 sebesar Rp1.526,40Triliun dan pada tahun 2017 sebesar Rp1.496,80 Triliun. Pada tahun 2018 meningkat dari tahun sebelumnya menjadi sebesar Rp1.578,20 Triliun.Sedangkan Belanja daerah yang paling rendah pada tahun 2015 adalah Kabupaten Kerinci sebesar Rp 918,90 Triliun.Padatahun 2016 sebesar Rp882,84 Triliun dan pada tahun 2017 sebesar Rp883,51 Triliun. Pada tahun 2018 meningkat menjadi sebesar Rp892,54 Triliun.

Besar kecilnya Belanja Daerah di sebabkan oleh beberapa faktor yang mempengaruhi yang mana apabila faktor tersebut di kelola dengan baik maka akan meningkatkan Belanja Daerah dan apabila Belanja Daerah meningkat maka kebutuhan akan kepentingan daerah juga akan meningkat serta membuat perekonomian menjadi lebih baik. Berdasarkan latar belakang maka peneliti ingin melakukan penelitian mengenai "Pengaruh Belanja Daerah terhadap pertumbuhan ekonomi dan kemiskinan Kabupaten/Kota di provinsi Jambi Periode 2015-2018" dengan rumusan masalah yaitu: 1).Bagaimana perkembangan Belanja Daerah, Pertumbuhan Ekonomi Dan Tingkat Kemiskinan di Kabupaten dan Kota di Provinsi Jambi Tahun 2015-2018?, 2).Bagaimana Pengaruh Belanja Daerah terhadap Pertumbuhan Ekonomi di Kabupaten dan Kota di Provinsi Jambi Tahun 2015-2018?, 3).Bagaimana Pengaruh Belanja Daerah terhadap Tingkat Kemiskinan di Kabupaten dan Kota di Provinsi Jambi Tahun 2015-2018?

\section{METODE}

Jenis data yang digunakan adalah data sekunder periode waktu 2015-2018 sebanyak 11 Kabupaten/kota di Provinsi Jambi. Metode analisis data dalam penelitian ini adalah metode deskriptif dan kuantitatif.

\section{Deskriptif}

Metode deskriptif merupakan metode yang digunakan untuk melihat perkembangan variabel dalam penelitian dengan menggunakan rumus sebagai berikuit: 


$$
L V P_{i t}=\frac{L V P_{i t}-L V P_{i t-1}}{L V P_{i t-1}} X 100 \%
$$

Keterangan :

$L V P_{i t} \quad=$ Laju perkembangan BD,PE, dan TK pada tahun $\mathrm{n}$

$L V P_{i t} \quad=$ Laju perkembangan tahun sekarang

$L V P_{i t-1}=$ Laju perkembangan tahun sebelumnya

\section{Metode kuantitatif}

Metode kuantitatif merupakan metode yang dilakukan untuk melihat pengaruh variabel bebas terhadap variabel terikat dengan menggunakan regresi data panel dengan 3 pendekatan sebagai berikut: 1).Pendekatan Commonded Effect, 2).Pendekatan Fixed Effect, 3).Pendekatan Random Effect

Dengan persamaan sebagai berikut:

$P E i t=\alpha+\beta 1 \log B$ Dit + eit $\ldots(1)$

TKit $=\alpha+\beta 1 \log B$ Dit + eit $\ldots$ (2)

Langkah-langkah penentuan model data panel sebagai berikut:

\section{Uji Chow}

$\mathrm{H}_{0}=$ Common effect

$\mathrm{H}_{\mathrm{I}}=$ Fixed effect

\section{Uji Hausman}

$\mathrm{H}_{0}=$ Random effect

$\mathrm{H}_{\mathrm{I}}=$ Fixed effect

\section{Uji LM}

$\mathrm{H}_{0}=$ Common effect

$\mathrm{H}_{\mathrm{I}}=$ Random effect

\section{HASIL DAN PEMBAHASAN}

\section{Perkembangan belanja daerah}

Belanja Daerah merupakan jumlah biaya yang dikeluarkan untuk belanja aparatur daerah, belanja pelayanan publik dan pembangunan. Belanja Daerah digunakan untuk mendanai segala urusan pemerintah yang menjadi kewenangan Provinsi maupun Kabupaten/Kota yang telah diserahkan kepada kepala daerah masing masing.

Dari tabel 1 dapat dilihat perkembangan Belanja Daerah pada Kabupaten/Kota di Provinsi Jambi dari tahun 2015 hingga 2018 sebesar 118,04 persen dengan perkembangan tertinggi pada Kabupaten Merangin sebesar 601.2 persen , diikuti oleh Kabupaten Muaro Jambi dengan rata-rata perkembangan sebesar 301.1 persen. Rata-rata perkembangan Belanja Daerah pada kabupaten/kota di Provinsi Jambi yang terendah berada di Kabupaten Bungo dengan persentase perkembangan sebesar 4.6 persen. Selanjutnya Kota Sungai Penuh rata-rata perkembangan nya sebesar 2.7 persen. 
Tabel 1. Perkembangan belanja daerah Kabupaten/kota di Provinsi Jambi Tahun 2015-2018 (persen)

\begin{tabular}{|c|c|c|c|c|c|}
\hline \multirow{2}{*}{$\begin{array}{l}\text { Kabupaten/ } \\
\text { Kota }\end{array}$} & \multicolumn{4}{|c|}{ Belanja Daerah di provinsi jambi (\%) } & \multirow{2}{*}{$\begin{array}{c}\text { Rata-rata } \\
\text { perkembangan } \\
(\%)\end{array}$} \\
\hline & 2015 & 2016 & 2017 & 2018 & \\
\hline Kerinci & - & -0.06 & 12.38 & -0.76 & 3.9 \\
\hline Merangin & - & 994.16 & -99.89 & 909.35 & 601.2 \\
\hline Sarolangun & - & -3.87 & 0.08 & 1.06 & -0.91 \\
\hline Batang Hari & - & 6.52 & -0.98 & 701.37 & 235.6 \\
\hline Muaro Jambi & - & -99.99 & 9.8 & 993.37 & 301.1 \\
\hline Tanjab Timur & - & -99.88 & 975.23 & -0.05 & 291.7 \\
\hline Tanjab Barat & - & -1.62 & 26.36 & 3.43 & 9.4 \\
\hline Tebo & - & 15.09 & -14.13 & 9.05 & 3.3 \\
\hline Bungo & - & 9.65 & -6.01 & 10.15 & 4.6 \\
\hline Kota Jambi & - & 7 & -1.97 & 5.49 & 3.5 \\
\hline Kota Sungai & - & 8.71 & -7.59 & 7 & \\
\hline Penuh & & & & & 2.7 \\
\hline \multicolumn{5}{|c|}{ rata-rata } & 132.4 \\
\hline
\end{tabular}

Sumber: BPS (diolah)

\section{Perkembangan pertumbuhan ekonomi}

Pertumbuhan ekonomi merupakan peningkatan dalam produksi barang dan jasa ekonomi, dibandingkan dari satu periode ke periode lainnya. Hal ini dapat diukur secara nominal atau riil (disesuaikan dengan tingkat inflasi) pada yang terjadi pada suatu negara. Dari tabel 2 dilihat rata-rata perkembangan Pertumbuhan Ekonomi pada Kabupaten/Kota Di Provinsi Jambi tahun 2015 hingga 2018 sebesar 4,8 persen, dari 11 Kabupaten/kota di Provinsi Jambi perkembangan Pertumbuhan Ekonomi tertinggi ada pada Kota Jambi dan Kota Sungai Penuh dengan rata-rata perkembangan selama empat tahun sebesar 6,3 persen diikuti oleh Kabupaten Kerinci dengan rata-rata perkembangan sebesar 6,08 persen.

Tabel 2. Perkembangan pertumbuhan ekonomi Kabupaten/kota di Provinsi Jambi Tahun 2015-2018 (persen)

\begin{tabular}{|c|c|c|c|c|c|}
\hline \multirow{2}{*}{$\begin{array}{c}\text { Kabupaten/ } \\
\text { Kota }\end{array}$} & \multicolumn{4}{|c|}{$\begin{array}{c}\text { Pertumbuhan ekonomi di provinsi jambi } \\
(\%)\end{array}$} & \multirow{2}{*}{$\begin{array}{c}\text { Rata-rata } \\
\text { perkembangan } \\
(\%)\end{array}$} \\
\hline & 2015 & 2016 & 2017 & 2018 & \\
\hline batang hari & 4.2 & 4.6 & 4.8 & 4.9 & 4.63 \\
\hline Bungo & 5.1 & 5.4 & 5.6 & 4.7 & 5.2 \\
\hline Kerinci & 6.4 & 6.7 & 6.1 & 5.1 & 6.08 \\
\hline Merangin & 5.4 & 6.2 & 5.4 & 5.2 & 5.55 \\
\hline muaro jambi & 5.2 & 5.4 & 5.1 & 5.4 & 5.28 \\
\hline Sarolangun & -1.4 & 4.3 & 4.4 & 4.7 & 3 \\
\hline Tanjabbar & -1.6 & 3.6 & 3.1 & 4.5 & 2.4 \\
\hline Tanjabtim & 1.8 & 2.7 & 3.1 & 3 & 2.65 \\
\hline Tebo & 5.3 & 5.3 & 5.5 & 5 & 5.28 \\
\hline Kota Jambi & 5.5 & 6.3 & 4.6 & 8.8 & 6.3 \\
\hline Kota Sungai Penuh & 7 & 6.5 & 6.2 & 5.5 & 6.3 \\
\hline \multicolumn{5}{|c|}{ Rata-Rata } & 4.8 \\
\hline
\end{tabular}

Sumber: BPS (diolah) 
Selanjutnya untuk rata-rata pertumbuhan ekonomi terendah berada di Kabupaten Tanjung Jabung Barat dengan persentase sebesar 2,4 persen terjadi perkembangan yang fluktuatif, Diikuti oleh Kabupaten Tanjung Jabung Timur dengan rata-rata perkembangan sebesar 2,65 persen meskipun mengalami perkembangan yang relatif rendah namun selalu terjadi peningkatan setiap tahunnya dari 1,8 persen di tahun 2015 meningkat menjadi 3 persen di tahun 2018 .

\section{Perkembangan tingkat kemiskinan}

Kemiskinan didefinisikan sebagai kondisi dimana seseorang atau sekelompok orang, laki-laki dan perempuan, tidak terpenuhi hak-hak dasarnya untuk memperoleh kehidupan yang layak seperti kebutuhan pangan, kesehatan, pendidikan, pekerjaan dan lainnya. Dari tabel 3 dapat dilihat rata-rata perkembangan Tingkat Kemiskinan di Kabupaten/Kota di Provinsi Jambi dari tahun 2015 hingga 2018 sebesar 8,22 persen. Dari 11 kabupaten/kota yang ada di Provinsi Jambi rata-rata perkembangan Tingkat Kemiskinan tertinggi berada di Kabupaten Tanjung Jabung Timur dengan rata-rata perkembangan selama empat tahun sebesar 12,97 persen diikuti oleh Kabupaten Tanjung Jabung Barat sebesar 11,72 persen. Untuk rata-rata Tingkat Kemiskinan terendah berada di Kota Sungai Penuh dengan rata-rata perkembangan sebesar 3,02 persen dengan tingkat kemiskinan sebesar 3,43 persen di tahun 2015 menurun menjadi 2,76 persen di tahun 2018.

Tabel 3. Perkembangan tingkat kemiskinan Kabupaten/Kota Tahun 2015-2018 (persen)

\begin{tabular}{lccccc}
\hline \multirow{2}{*}{\multicolumn{1}{c}{ Kabupaten/Kota }} & \multicolumn{3}{c}{ Tingkat kemiskinan Kabupaten/Kota } & di Provinsi Jambi \\
\cline { 2 - 5 } & $\mathbf{2 0 1 5}$ & $\mathbf{2 0 1 6}$ & $\mathbf{2 0 1 7}$ & $\mathbf{2 0 1 8}$ & $\begin{array}{c}\text { Rata-rata } \\
\text { perkembangan (\%) }\end{array}$ \\
\cline { 2 - 5 } Kab. Kerinci & 8.16 & 7.15 & 7.45 & 7.07 & 7.46 \\
Kab. Merangin & 9.80 & 9.95 & 9.43 & 8.88 & 9.52 \\
Kab. Sarolangun & 10.29 & 9.33 & 8.87 & 8.73 & 9.31 \\
Kab. Batang Hari & 10.69 & 10.79 & 10.33 & 10.23 & 10.51 \\
Kab. Muaro Jambi & 4.63 & 4.30 & 4.37 & 4.05 & 4.34 \\
Kab. Tanjung Jabung Timur & 14.17 & 12.76 & 12.58 & 12.38 & 12.97 \\
Kab. Tanjung Jabung Barat & 12.63 & 11.81 & 11.32 & 11.1 & 11.72 \\
Kab. Tebo & 7.12 & 6.87 & 6.79 & 6.58 & 6.84 \\
Kab. Bungo & 5.70 & 5.99 & 5.82 & 5.78 & 5.82 \\
Kota Jambi & 9.67 & 8.87 & 8.84 & 8.49 & 8.97 \\
Kota Sungai Penuh & 3.43 & 3.13 & 2.78 & 2.76 & 3.02 \\
\hline & Rata-Rata & & & $\mathbf{8 . 2 2}$ \\
\hline
\end{tabular}

Sumber :BPS (diolah)

Analisis pengaruh belanja daerah terhadap pertumbuhan ekonomi Kabupaten dan Kota di Provinsi Jambi Tahun 2015-2018

Hasil dari pengolahan data dengan menggunakan Common Effect sebagai berikut:

PEit $\quad=5.403800-0.028860$ BDit

$\mathrm{t}$-Statistic $\quad=(5.946067) \quad(-0.714234)$

Prob. $\quad=(0.0000) \quad(0.4790)$ 


\section{Fixed effect}

Hasil dari pengolahan data dengan pendekatan Fixed Effect sebagai berikut:

PEit $\quad=4.871991-0.004002 \mathrm{BDit}$

t-Statistic $=(3.206311) \quad(-0.056909)$

Prob. $\quad=(0.0030) \quad(0.9550)$

Tabel 4. Nilai intersep fixed effect Provinsi Jambi

\begin{tabular}{llc}
\hline NO & Kabupaten/Kota & Nilai Intersep Pertumbuhan Ekonomi \\
\hline 1 & Kerinci & -0.136006 \\
2 & Merangin & 0.425206 \\
3 & Sarolangun & 1.257855 \\
4 & Batang Hari & 0.789019 \\
5 & Muaro Jambi & 0.479594 \\
6 & Tanjab Timur & -1.768719 \\
7 & Tanjab Barat & -2.416167 \\
8 & Tebo & -2.111512 \\
9 & Bungo & 0.458226 \\
10 & Kota Jambi & 1.540238 \\
11 & Kota Sungai Penuh & 1.482267 \\
\hline
\end{tabular}

Sumber: Data diolah

\section{Random effect}

Hasil dari pengolahan data dengan pendekatan Random Effect sebagai berikut:

PEit $\quad=5.188882-0.018814 \mathrm{BDit}$

$\mathrm{t}$-Statistic $=(4.423937) \quad(-0.372238)$

Prob. $\quad=(0.0001) \quad(0.7116)$

Tabel 5. Nilai intersep random effect Provinsi Jambi

\begin{tabular}{llc}
\hline NO & Kabupaten/Kota & Nilai Intersep Pertumbuhan Ekonomi \\
\hline 1 & Kerinci & -0.032990 \\
2 & Merangin & 0.366208 \\
3 & Sarolangun & 0.895086 \\
4 & Batang Hari & 0.690877 \\
5 & Muaro Jambi & 0.349080 \\
6 & Tanjab Timur & -1.332859 \\
7 & Tanjab Barat & -1.976857 \\
8 & Tebo & -1.580211 \\
9 & Bungo & 0.270484 \\
10 & Kota Jambi & 1.282204 \\
11 & Kota Sungai Penuh & 1.068978 \\
\hline
\end{tabular}

Sumber: Data diolah

\section{Pemilihan model estimasi}

Berdasarkan hasil regresi data panel dengan pendekatan common effect, fixed effect dan random effect maka langkah berikutnya adalah pemilihan model terbaik yang dilakukan dengan Uji Chow, Uji Hausman Dan Uji LM. 


\section{Uji Chow}

Uji Chow bertujuan untuk mengetahui apakah sebaiknya model menggunakan common effect ataukah fixed effect. Hipotesis dalam Uji ini adalah sebagai berikut:

$\mathrm{H}_{0}=$ Common effect

$\mathrm{H}_{\mathrm{I}}=$ Fixed effect

Apabila nilai dari probabilitas Chi-Square kurang dari 5\% maka $\mathrm{H}_{0}$ ditolak. Sehingga model yang terbaik adalah fixed effect.

Tabel 6. Hasil analisis uji chow

\begin{tabular}{lcrr}
\hline Effects Test & Statistic & d.f. & \multicolumn{1}{c}{ Prob. } \\
\hline Cross-section $\boldsymbol{F}$ & 4.152566 & $(10,32)$ & 0.001 \\
\hline Cross-section Chi-square & 36.60354 & 10 & 0.0001 \\
\hline
\end{tabular}

Sumber: Data diolah

Berdasarkan tabel 6 Dengan menggunakan nilai p-value dapat disimpulkan signifikan apabila kurang dari 5\% atau 10\% sehingga menggunakan estimasi Fixed Effect Model. Sedangkan p-value disimpulkan signifikan $0.001<\alpha 5 \%(0.05)$ maka menolak Ho dan menerima Ha maka model yang tepat adalah menggunakan estimasi Fixed Effect Model.

\section{Uji hausman}

Uji Hausman bertujuan untuk mengetahui apakah model Random Effect lebih baik digunakan dari pada model Fixed Effect. Hipotesis yang digunakan dalam Uji Hausman adalah sebagai berikut:

$\mathrm{H}_{0}=$ Random effect

$\mathrm{H}_{\mathrm{I}}=$ Fixed effect

Apabila nilai probabilitas chi-square lebih dari 5\%, maka sebaiknya model menggunakan Random Effect.

Tabel 7. Hasil analisis uji hausman

\begin{tabular}{lrrr}
\hline Test Summary & Chi-Sq. Statistic & Chi-Sq. d.f. & Prob. \\
\hline Cross-section random & 0.091735 & 1 & 0.762 \\
\hline
\end{tabular}

Sumber: Data diolah

Berdasarkan tabel 7 Interpretasi Chi-square signifikan ( $\mathrm{p}$-value $=0.762>0.05$ ) sehingga Ho diterima. Dengan demikian dapat disimpulkan bahwa model yang terbaik dalam pengujian ini adalah model Random Effect Model.

\section{Uji lagrange multiplier (LM)}

Uji LM bertujuan untuk mengetahui apakah model Random Effect lebih baik digunakan dari pada model Common Effect. Hipotesis yang digunakan dalam penelitian ini adalah sebagai berikut:

$\mathrm{H}_{0}=$ Common effect

$\mathrm{H}_{\mathrm{I}}=$ Random effect

Apabila nilai probabilitas Breusch-Pagan $<5 \%$ maka $\mathrm{H}_{0}$ ditolak, maka sebaiknya model menggunakan Random Effect. 
Tabel 8. Hasil analisis uji LM

\begin{tabular}{lrrr}
\hline Test Hypothesis & Cross-section & Time & Both \\
\hline Breusch-Pagan & 12.04919 & 0.026348 & 12.07554 \\
& $(0.0005)$ & $(0.8711)$ & $(0.0005)$ \\
\hline
\end{tabular}

Sumber: Data diolah

Berdasarkan Tabel 8 diketahui nilai Both pada Breusch-Pagan sebesar $(0,0005)$. Nilai tersebut lebih kecil dari $\alpha(0,05)$ sehingga Ho ditolak. Dengan demikian dapat disimpulkan bahwa model regresi data panel yang direkomendasikan berdasarkan hasil uji lagrange multiplier adalah Random Effect Model (REM).

\section{Uji hipotesis}

Setelah memilih model yang terbaik dilanjutkan dengan uji hipotesis. Uji hipotesis dilakukan dengan uji signifikan statistik secara parsial atau uji-t.

\section{Uji parsial (Uji t)}

Dari hasil regresi Random Effect diperoleh nilai t-hitung untuk Belanja Daerah sebesar $-0,372238$ dengan signifikansi 0,7116 pada $\alpha=5 \%$ dan diperoleh $\mathrm{df}=\mathrm{n}-\mathrm{k}(44-3=41)$, didapat ttabel $=2.019$ dengan signifikansi 0,05 . maka thitung $=-0,3722<$ ttabel 2,019 dan signifikansi 0,7116 > 0,05. Dari perbandingan nilai thitung < ttabel menarik kesimpulan Ho diterima dan Ha di tolak. Artinya Belanja Daerah berpengaruh Negatif dan Tidak Signifikan Terhadap Pertumbuhan Ekonomi.

Tabel 9. Nilai intersep pertumbuhan ekonomi (Random Effect)

\begin{tabular}{llc}
\hline NO & Kabupaten/Kota & Nilai Intersep Pertumbuhan Ekonomi \\
\hline 1 & Kerinci & $(5,19-0,03=5,16)$ \\
2 & Merangin & $(5,19+0,37=5,56)$ \\
3 & Sarolangun & $(5,19+0,89=6,08)$ \\
4 & Batang Hari & $(5,19+0,69=5,88)$ \\
5 & Muaro Jambi & $(5,19+0,35=5,54)$ \\
6 & Tanjab Timur & $(5,19-1,33=3,86)$ \\
7 & Tanjab Barat & $(5,19-1,58=3,21)$ \\
8 & Tebo & $(5,19+0,27=5,46)$ \\
9 & Bungo & $(5,19+1,28=6,47)$ \\
10 & Kota Jambi & $(5,19+1,07=6,26)$ \\
11 & Kota Sungai Penuh &
\end{tabular}

\section{Sumber: Data diolah}

\section{Kabupaten Kerinci}

Artinya Pertumbuhan Ekonomi di Kabupaten Kerinci sudah terjadi walaupun tanpa Belanja Daerah sebab adanya faktor-faktor lain yang mempengaruhi Pertumbuhan Ekonomi selain Belanja Daerah. Dengan nilai intersep nya sebesar 5,16.

\section{Kabupaten Merangin}

Artinya Pertumbuhan Ekonomi di Kabupaten Merangin sudah terjadi walaupun tanpa Belanja Daerah sebab adanya faktor-faktor lain yang mempengaruhi Pertumbuhan Ekonomi selain Belanja Daerah. Dengan nilai intersep nya sebesar 5,56. 


\section{Kabupaten Sarolangun}

Artinya Pertumbuhan Ekonomi di Kabupaten Sarolangun sudah terjadi walaupun tanpa Belanja Daerah sebab adanya faktor-faktor lain yang mempengaruhi Pertumbuhan Ekonomi selain Belanja Daerah. Dengan nilai intersep nya sebesar 6,08.

\section{Kabupaten Batanghari}

Artinya Pertumbuhan Ekonomi di Kabupaten Batanghari sudah terjadi walaupun tanpa Belanja Daerah sebab adanya faktor-faktor lain yang mempengaruhi Pertumbuhan Ekonomi selain Belanja Daerah. Dengan nilai intersep nya sebesar 5,88.

\section{Kabupaten Muaro Jambi}

Artinya Pertumbuhan Ekonomi di Kabupaten Muaro Jambi sudah terjadi walaupun tanpa Belanja Daerah sebab adanya faktor-faktor lain yang mempengaruhi Pertumbuhan Ekonomi selain Belanja Daerah. Dengan nilai intersep nya sebesar 5,54.

\section{Kabupaten Tanjung Jabung Timur}

Artinya Pertumbuhan Ekonomi di Kabupaten Tanjung Jabung Timur sudah terjadi walaupun tanpa Belanja Daerah sebab adanya faktor-faktor lain yang mempengaruhi Pertumbuhan Ekonomi selain Belanja Daerah. Dengan nilai intersep nya sebesar 3,86.

\section{Kabupaten Tanjung Jabung Barat}

Artinya Pertumbuhan Ekonomi di Kabupaten Tanjung Jabung Barat sudah terjadi walaupun tanpa Belanja Daerah sebab adanya faktor-faktor lain yang mempengaruhi Pertumbuhan Ekonomi selain Belanja Daerah. Dengan nilai intersep nya sebesar 3,21

\section{Kabupaten Tebo}

Artinya Pertumbuhan Ekonomi di Kabupaten Tebo sudah terjadi walaupun tanpa Belanja Daerah sebab adanya faktor-faktor lain yang mempengaruhi Pertumbuhan Ekonomi selain Belanja Daerah. Dengan nilai intersep nya sebesar 3,61.

\section{Kabupaten Bungo}

Artinya Pertumbuhan Ekonomi di Kabupaten Bungo sudah terjadi walaupun tanpa Belanja Daerah sebab adanya faktor-faktor lain yang mempengaruhi Pertumbuhan Ekonomi selain Belanja Daerah. Dengan nilai intersep nya sebesar 5,46.

\section{Kota Jambi}

Artinya Pertumbuhan Ekonomi di Kota Jambi sudah terjadi walaupun tanpa Belanja Daerah sebab adanya faktor-faktor lain yang mempengaruhi Pertumbuhan Ekonomi selain Belanja Daerah. Dengan nilai intersep nya sebesar 6,47.

\section{Kota Sungai Penuh}

Artinya Pertumbuhan Ekonomi di Kota Sungai Penuh sudah terjadi walaupun tanpa Belanja Daerah sebab adanya faktor-faktor lain yang mempengaruhi Pertumbuhan Ekonomi selain Belanja Daerah. Dengan nilai intersep nya sebesar 6,26. 


\section{Analisis pengaruh belanja daerah terhadap kemiskinan \\ Common effect}

Hasil dari pengolahan data dengan menggunakan Common Effect sebagai berikut:

TKit $=5.314874+0.157939$ BDit

$\mathrm{t}$-Statistic $=(4.312263)(2.882153)$

Prob. $\quad=(0.0001) \quad(0.0062)$

\section{Fixed effect}

Hasil dari pengolahan data dengan pendekatan Fixed Effect sebagai berikut:

TKit

$\mathrm{t}-$ Statistic $\quad=(15.55586)(0.173332)$

Prob. $\quad=(0.0000) \quad(0.8635)$

Tabel 9. Nilai intersep fixed effect Provinsi Jambi

\begin{tabular}{llc}
\hline No & Kabupaten/Kota & Nilai intersep tingkat kemiskinan \\
\hline 1 & Kerinci & 1.788039 \\
2 & Merangin & -2.886683 \\
3 & Sarolangun & -1.204756 \\
4 & Batang Hari & 0.793012 \\
5 & Muaro Jambi & 0.831155 \\
6 & Tanjab Timur & 0.591586 \\
7 & Tanjab Barat & 3.054160 \\
8 & Tebo & 4.248600 \\
9 & Bungo & -1.822668 \\
10 & Kota Jambi & 0.244161 \\
11 & Kota Sungai Penuh & -5.636605 \\
\hline
\end{tabular}

Sumber: Data diolah

\section{Random effect}

Hasil dari pengolahan data dengan pendekatan Random Effect sebagai berikut:

TKit $=8.439711+0.011879 \mathrm{BDit}$

$\mathrm{t}$-Statistic $=(8.836979)(0.473722)$

Prob. $\quad=(0.0000) \quad(0.6382)$

Tabel 10. Nilai intersep random effect Provinsi Jambi

\begin{tabular}{llc}
\hline No & Kabupaten/Kota & Nilai Intersep Tingkat Kemiskinan \\
\hline 1 & Kerinci & -0.032990 \\
2 & Merangin & 0.366208 \\
3 & Sarolangun & 0.895086 \\
4 & Batang Hari & 0.690877 \\
5 & Muaro Jambi & 0.349080 \\
6 & Tanjab Timur & -1.332859 \\
7 & Tanjab Barat & -1.976857 \\
8 & Tebo & -1.580211 \\
9 & Bungo & 0.270484 \\
10 & Kota Jambi & 1.282204 \\
11 & Kota Sungai Penuh & 1.068978 \\
\hline
\end{tabular}

Sumber: Data diolah 


\section{Pemilihan model estimasi}

Berdasarkan hasil regresi data panel dengan pendekatan common effect, fixed effect dan random effect maka langkah berikutnya adalah pemilihan model terbaik yang dilakukan dengan Uji Chow, Uji Hausman Dan Uji LM.

\section{Uji Chow}

Uji Chow bertujuan untuk mengetahui apakah sebaiknya model menggunakan common effect ataukah fixed effect. Hipotesis dalam Uji ini adalah sebagai berikut:

$\mathrm{H}_{0}=$ Common effect

$\mathrm{H}_{\mathrm{I}}=$ Fixed effect

Apabila nilai dari probabilitas Chi-Square kurang dari 5\% maka $\mathrm{H}_{0}$ ditolak. Sehingga model yang terbaik adalah fixed effect.

Tabel 11. Hasil analisis uji chow

\begin{tabular}{lrrr}
\hline Effects Test & Statistic & d.f. & Prob. \\
\hline Cross-section $\boldsymbol{F}$ & 98.981228 & $(10,32)$ & 0.0000 \\
Cross-section Chi-square & 152.398276 & 10 & 0.0000 \\
\hline
\end{tabular}

Sumber: Data diolah, 2020

Berdasarkan Tabel 11 Dengan menggunakan nilai p-value dapat disimpulkan signifikan apabila kurang dari 5\% atau 10\% sehingga menggunakan estimasi Fixed Effect Model. Sedangkan p-value disimpulkan signifikan $0.0000<\alpha 5 \%(0.05)$ maka menolak Ho dan menerima Ha maka model yang tepat adalah menggunakan estimasi Fixed Effect Model.

\section{Uji hausman}

Uji Hausman bertujuan untuk mengetahui apakah model Random Effect lebih baik digunakan dari pada model Fixed Effect. Hipotesis yang digunakan dalam Uji Hausman adalah sebagai berikut:

$\mathrm{H}_{0}=$ Random effect

$\mathrm{H}_{\mathrm{I}}=$ Fixed effect

Apabila nilai probabilitas chi-square lebih dari 5\%, maka sebaiknya model menggunakan Random Effect.

Tabel 12. Hasil analisis uji hausman

\begin{tabular}{llll}
\hline Test Summary & Chi-Sq. Statistic & Chi-Sq. d.f. & Prob. \\
\hline Cross-section random & 2.151425 & 1 & 0.1424 \\
\hline
\end{tabular}

Sumber: Data diolah, 2020

Berdasarkan Tabel 11 Interpretasi Chi-square signifikan ( $\mathrm{p}$-value $=0,1424>0.05$ ) sehingga Ho diterima. Dengan demikian dapat disimpulkan bahwa model yang terbaik dalam pengujian ini adalah model Random Effect Model.

\section{Uji lagrange multiplier (LM)}

Uji LM bertujuan untuk mengetahui apakah model Random Effect lebih baik digunakan dari pada model Common Effect. Hipotesis yang digunakan dalam penelitian ini adalah sebagai berikut: 
$\mathrm{H}_{0}=$ Common effect

$\mathrm{H}_{\mathrm{I}}=$ Random effect

Apabila nilai probabilitas Breusch-Pagan $<5 \%$ maka $\mathrm{H}_{0}$ ditolak, maka sebaiknya model menggunakan Random Effect.

Tabel 13. Hasil analisis uji LM

\begin{tabular}{lrrr}
\hline Test Hypothesis & Cross-section & Time & Both \\
\hline \multirow{2}{*}{ Breusch-Pagan } & 59.85480 & 1.397223 & 61.25202 \\
& $(0.0000)$ & $(0.2372)$ & $(0.0000)$ \\
\hline
\end{tabular}

Sumber: Data diolah, 2020

Berdasarkan Tabel 13 diketahui nilai Both pada Breusch-Pagan sebesar $(0,0005)$. Nilai tersebut lebih kecil dari a $(0,05)$ sehingga Ho ditolak. Dengan demikian dapat disimpulkan bahwa model regresi data panel yang direkomendasikan berdasarkan hasil uji lagrange multiplier adalah Random Effect Model (REM).

\section{Uji hipotesis}

Setelah memilih model mana yang terbaik dilanjutkan dengan uji hipotesis. Uji hipotesis dilakukan dengan uji signifikan statistik secara parsial atau uji-t.

\section{Uji parsial (Uji t)}

Dari hasil regresi Random Effect diperoleh nilai t-hitung untuk Belanja Daerah sebesar 0,473722 dengan signifikansi 0,6382 pada $\alpha=5 \%$ dan diperoleh $\mathrm{df}=\mathrm{n}-\mathrm{k}(44-3=41)$, didapat ttabel $=2.019$ dengan signifikansi 0,05. maka thitung $=0,4737<$ ttabel 2,019 dan signifikansi 0,6382 >0,05. Dari perbandingan nilai thitung < ttabel menarik kesimpulan Ho diterima dan Ha di tolak. Artinya Belanja Daerah berpengaruh Positif dan Tidak Signifikan Terhadap Tingkat Kemiskinan.

Tabel 14. Nilai intersep tingkat kemiskinan (Random Effect)

\begin{tabular}{llc} 
No & Kabupaten/Kota & Nilai intersep tingkat kemiskinan \\
\hline 1 & Kerinci & $(8,44+1,72=10,16)$ \\
2 & Merangin & $(8,44-2,88=5,56)$ \\
3 & Sarolangun & $(8,44-1,14=7,3)$ \\
4 & Batang Hari & $(8,44+0,74=9,18)$ \\
5 & Muaro Jambi & $(8,44+0,84=9,28)$ \\
6 & Tanjab Timur & $(8,44+0,55=8,99)$ \\
7 & Tanjab Barat & $(8,44+3,88=12,32)$ \\
8 & Tebo & $(8,44+4,16=12,6)$ \\
9 & Bungo & $(8,44-1,75=6,69)$ \\
10 & Kota Jambi & $(8,44+0,19=8,63)$ \\
11 & Kota Sungai Penuh & $(8,44-5,53=2,91)$ \\
\hline
\end{tabular}

Sumber: Data diolah, 2020 


\section{Kabupaten Kerinci}

Artinya Pertumbuhan Ekonomi di Kabupaten kerinci sudah terjadi walaupun tanpa Belanja Daerah sebab adanya faktor-faktor lain yang mempengaruhi Pertumbuhan Ekonomi selain Belanja Daerah. Dengan nilai intersep nya sebesar 10,16.

\section{Kabupaten Merangin}

Artinya Pertumbuhan Ekonomi di Kabupaten Merangin sudah terjadi walaupun tanpa Belanja Daerah sebab adanya faktor-faktor lain yang mempengaruhi Pertumbuhan Ekonomi selain Belanja Daerah. Dengan nilai intersep nya sebesar 5,56.

\section{Kabupaten Sarolangun}

Artinya Pertumbuhan Ekonomi di Kabupaten Sarolangun sudah terjadi walaupun tanpa Belanja Daerah sebab adanya faktor-faktor lain yang mempengaruhi Pertumbuhan Ekonomi selain Belanja Daerah. Dengan nilai intersep nya sebesar 7,3.

\section{Kabupaten Batanghari}

Artinya Pertumbuhan Ekonomi di Kabupaten Batanghari sudah terjadi walaupun tanpa Belanja Daerah sebab adanya faktor-faktor lain yang mempengaruhi Pertumbuhan Ekonomi selain Belanja Daerah. Dengan nilai intersep nya sebesar 9,18.

\section{Kabupaten Muaro Jambi}

Artinya Pertumbuhan Ekonomi di Kabupaten Muaro Jambi sudah terjadi walaupun tanpa Belanja Daerah sebab adanya faktor-faktor lain yang mempengaruhi Pertumbuhan Ekonomi selain Belanja Daerah. Dengan nilai intersep nya sebesar 9,28.

\section{Kabupaten Tanjung Jabung Timur}

Artinya Pertumbuhan Ekonomi di Kabupaten Tanjung Jabung Timur sudah terjadi walaupun tanpa Belanja Daerah sebab adanya faktor-faktor lain yang mempengaruhi Pertumbuhan Ekonomi selain Belanja Daerah. Dengan nilai intersep nya sebesar 8,99.

\section{Kabupaten Tanjung Jabung Barat}

Artinya Pertumbuhan Ekonomi di Kabupaten Tanjung Jabung Barat sudah terjadi walaupun tanpa Belanja Daerah sebab adanya faktor-faktor lain yang mempengaruhi Pertumbuhan Ekonomi selain Belanja Daerah. Dengan nilai intersep nya sebesar 12,32.

\section{Kabupaten Tebo}

Artinya Pertumbuhan Ekonomi di Kabupaten Tebo sudah terjadi walaupun tanpa Belanja Daerah sebab adanya faktor-faktor lain yang mempengaruhi Pertumbuhan Ekonomi selain Belanja Daerah. Dengan nilai intersep nya sebesar 12,6.

\section{Kabupaten Bungo}

Artinya Pertumbuhan Ekonomi di Kabupaten Bungo sudah terjadi walaupun tanpa Belanja Daerah sebab adanya faktor-faktor lain yang mempengaruhi Pertumbuhan Ekonomi selain Belanja Daerah. Dengan nilai intersep nya sebesar 6,69. 


\section{Kota Jambi}

Artinya Pertumbuhan Ekonomi di Kota Jambi sudah terjadi walaupun tanpa Belanja Daerah sebab adanya faktor-faktor lain yang mempengaruhi Pertumbuhan Ekonomi selain Belanja Daerah. Dengan nilai intersep nya sebesar 8,63.

\section{Kota Sungai Penuh}

Artinya Pertumbuhan Ekonomi di Kota Sungai Penuh sudah terjadi walaupun tanpa Belanja Daerah sebab adanya faktor-faktor lain yang mempengaruhi Pertumbuhan Ekonomi selain Belanja Daerah. Dengan nilai intersep nya sebesar 2,91.

\section{Implikasi hasil penelitian}

Dari hasil regresi diatas menunjukan bahwa pengaruh Belanja Daerah terhadap Tingkat Kemiskinan di Kabupaten/kota di Provinsi Jambi berpengaruh Positif dan Tidak Signifikan. Sejalan dengan penelitian Cordelia (2019) di Nigeria yang berjudul "Government Sectoral Expenditure and Poverty Alleviation in Nigeria" menunjukkan bahwa pengeluaran pemerintah untuk pertanian, bangunan dan konstruksi, pendidikan dan kesehatan tidak memiliki pengaruh yang signifikan terhadap pengentasan kemiskinan di Nigeria. Oleh karena itu, studi tersebut menyimpulkan bahwa pengeluaran pemerintah tidak mencukupi dan merekomendasikan agar lebih banyak dana dianggarkan untuk meningkatkan sektor ini guna memberantas masalah kemiskinan tersebut.

Adapun program yang dijalankan oleh pemerintah Jambi dalam upayanya untuk menanggulangi kemiskinan di daerah adalah sebagai berikut: 1).Pembagian Beras Bersubsidi, 2).Program Kredit Usaha Mikro

Kelompok Usaha Bersama atau KUB adalah bentuk industri rumahan yang kegiatannya memanfaatkan benda di sekitar lingkungan untuk dijadikan komoditas yang bernilai ekonomis. Namun kenyataannya di Provinsi Jambi masyarakat menengah kebawah lebih suka mengambil langkah yang instan dari pada melakukan yang menurut mereka terlalu sulit untuk dilakukan. Ini adalah salah satu penyebab tinggi nya tingkat kemiskinan Kabupaten dan Kota di Provinsi Jambi. Terkait dengan hal diatas, penciptaan lapangan kerja guna mengurangi pengangguran perlu digunakan suasana yang kondusif demi tersemainya kewirausahaan dikalangan warga. Salah satu problematika yang masih ada adalah sulitnya usaha kecil untuk berkembang. selama ini hambatan structural seperti sulitnya aturan formalisasi yang mewajibkan mereka untuk memenuhi persyaratan legal formal.

\section{Pengaruh belanja daerah terhadap pertumbuhan ekonomi di Kabupaten dan Kota di Provinsi Jambi}

Dari hasil regresi diatas menunjukan bahwa pengaruh Belanja Daerah terhadap Pertumbuhan Ekonomi di Kabupaten/kota di Provinsi Jambi berpengaruh negatif dan Tidak Signifikan. Dalam Teori Pertumbuhan Klasik menurut Ricardo dan Mill, dalam jangka Panjang perekonomian akan mencapai stationary state, dimana suatu keadaan perkembangan ekonomi tidak terjadi sama sekali. Hal ini sejalan dengan hasil penelitian Lendy (2019) di manado yang berjudul " Pengaruh Pengeluaran Pemerintah, Investasi, dan Tenaga Kerja terhadap Pertumbuhan Ekonomi di Kota Manado" pengeluaran pemerintah tidak berpengaruh terhadap pertumbuhan ekonomi di Kota Manado sedangkan variabel investasi dan tenaga kerja berpengaruh dan signifikan. dengan kata lain, ada variabel lain yang lebih 
dominan mempengaruhi pertumbuhan ekonomi contonya variabel konsumsi, tabungan, suku bunga, inflasi, ekspor, impor, dan lainnya.

Sedangkan hasil penelitian Pascual (2017) di Negara-negara Uni Europe yang berjudul "Government expenditure and economic growth in the European Union countries " Hasil menunjukkan pengeluaran pemerintah tidak terkait dengan pertumbuhan ekonomi di negara Uni Eropa, mereka menemukan hubungan positif untuk beberapa negara UE (Portugal dan Inggris) sedangkan untuk negara lain (Austria, Finlandia, Italia dan Swedia) negatif atau bahkan tidak signifikan (Belgia, Prancis, Yunani, Irlandia, Luksemburg, Belanda dan Spanyol). Namun negara Eropa secara keseluruhan negatif selama periode 1994-2012.

Secara real di Provinsi Jambi kurun waktu 4 tahun adalah realisasi belanja barang untuk pemeliharaan infrastruktur dan belanja modal pada akhir tahun seringkali masih di bawah target, atau lebih rendah apabila dibandingkan dengan anggarannya. Disamping itu, masih banyak daerah yang mengalokasikan porsi belanja pegawai yang lebih besar dari alokasi belanja barang untuk pemeliharaan infrastruktur dan belanja modal untuk pelayanan publik. Kondisi tersebut akan menyebabkan APBD tidak mampu untuk mendukung peningkatan pertumbuhan ekonomi daerah.

\section{KESIMPULAN DAN SARAN}

\section{Kesimpulan}

Perkembangan Belanja Daerah, Pertumbuhan Ekonomi dan Tingkat Kemiskinan Kabupaten dan Kota di Provinsi Jambi selama empat tahun mengalami perkembangan yang cukup bagus dengan rata-rata perkembangan Belanja Daerah sebesar 132.4 persen, selanjutnya rata-rata perkembangan Pertumbuhan Ekonomi sebesar 4,8 persen dan Tingkat Kemiskinan dengan rata-rata perkembangan sebesar 8,22 persen. Variabel Pertumbuhan Ekonomi (Y1) memilih metode Random Effect dan menarik kesimpulan bahwa Belanja Daerah berpengaruh negatif dan Tidak Signifikan terhadap Pertumbuhan Ekonomi Kabupaten dan Kota di Provinsi Jambi periode 2015 hingga 2018. Sedangkan Variabel Tingkat Kemiskinan (Y2) memilih Random Effect dan menarik kesimpulan bahwa Belanja Daerah berpengaruh positif dan Tidak Signifikan terhadap Tingkat Kemiskinan Kabupaten dan Kota di Provinsi Jambi periode 2015 hingga 2018.

\section{Saran}

Pemerintah setiap kabupaten/kota di Provinsi Jambi harus mampu mengatur porsi belanja barang, belanja modal, dan belanja transfer ditingkatkan untuk membiayai kegiatan produktif, seperti peningkatan infrastruktur di desa maupun perintisan industri rumahan (home industry). Dan menyalurkan dana belanja daerah untuk penambahan lapangan pekerjaan maupun pendapatan baru untuk masyarakat. Pemerintah harus mampu menciptakan lapangan kerja produktif dalam jumlah besar. Untuk mencapai kondisi tersebut, perlu diciptakan iklim usaha yang kondusif di daerah.

\section{DAFTAR PUSTAKA}

A Devita., A Delis., \& J Junaidi. (2014).Pengaruh pendapatan asli daerah, dana alokasi umum dan jumlah penduduk terhadap belanja daerah Kabupaten/Kota di Provinsi Jambi, Jurnal Perspektif Pembiayaan dan Pembangunan Daerah. 2 (2), 63-70

Abdillah, Khubbi., \& Mursinto, Djoko. (2016). The effects of financial balance transfer and regional own-source revenue on regional expenditure of regencies and 
municipalities in East Java Province. International Journal of Scientific and Research Publications, 6(5): 26-30

Abdul, Halim. (2004). Akuntansi keuangan daerah. UPP AMP YKPN: Yogyakarta

Albornoz, M. A., Becker, M., Cahyat, A., Cronkleton, P., Jong, W.d., Evans, K., \& Wollenberg, E. (2007). Menuju kesejahteraan dalam masyarakat hutan: buku panduan untuk pemerintah daerah, Cifor: Bogor

Gujarati, Damodar N. (2003). Dasar-dasar Ekonometrika. Salemba Empat: Jakarta

Koyongian, Kindangen, Kawung. (2019). Pengaruh pengeluaran pemerintah, investasi, dan tenaga kerja terhadap pertumbuhan ekonomi Kota Manado. Fakultas Ekonomi dan Binis, Magister Ilmu Ekonomi dan BisnisUniversitas Sam Ratulangi: Manado

Mangkoesoebroto, Guritno. (1993). Ekonomi publik, Edisi-III, BPFE: Yogyakarta.

Mangkoesoebroto, Guritno. (2001). Ekonomi publik, Edisi-III, BPFE: Yogyakarta.

Mankiw, N. Gregory. (2003). Teori makro ekonomi, Erlangga: Jakarta

Musgrave, Richard A. (1991). Keuangan negara: dalam teori dan praktek richard a musgrave public finance in theory and practice keuangan.Erlangga: Jakarta.

Rochmatullah, Mahameru Rosy, Hartanto., Rudy, \& Arifin, Atwal. (2016). Determinating the value of capital expenditure allocation in Indonesia local government. Jurnal Ekonomi Pembangunan, 17(2) :152-166

S Rahmadi., \& M Safri. (2014).Peningkatan belanja modal dan hubungannya terhadap peningkatan belanja aset dan PAD Provinsi Jambi, Jurnal Paradigma Ekonomika 9 (1)

S Sunargo., \& D Hastuti. (2019).Mengatasi perilaku kerja kontraproduktif melalui peran integratif politik organisasional dan kecerdasan emosional pada era revolusi industri 4.0, Jurnal Paradigma Ekonomika 14 (2), 45-54

Saez, Garcia, Rodriguez. (2017). Government expenditure and economic growth in the European Union countries: New evidence

Sukirno, Sadono. (2011). Makro ekonomi teori pengantar Edisi Ketiga.Rajawali Pers: Jakarta

Suyanto, Bagong.(2013), Anatomi kemiskinan dan strategi penanganannya, Intrans Publishing: Malang.

Thomas Aquinas Salem. (2018). Pengaruh pertumbuhan ekonomi daerah, belanja daerah, dan tingkat kemiskinan terhadap indeks pembangunan manusia (IPM) di Provinsi NTT Periode 2001-2016.Universitas Sanata Dharma:Yogyakarta. 